\title{
Characterization of Arthrospira sp (Spirulina) biomass grown in hydroponic waste solution: a review
}

\author{
Yan Valdez Santos Rodrigues ${ }^{1}$, Edna Dos Santos Almeida ${ }^{2}$, Erika Durão Vieira ${ }^{3}$, \\ ${ }^{1}$ Centro Universitário SENAI CIMATEC, Brasil, \\ ${ }^{2}$ Environment, Centro Universitário SENAI CIMATEC \\ ${ }^{3}$ Biotecnology, Centro Universitário SENAI CIMATEC
}

\begin{abstract}
:
The use of Spirulina (Arthospira sp) as a food source has stood out for being a potential source of proteins, fatty acids, vitamins and others. However, the cultivation medium for its production is still expensive. We observed that in hydroponics systems a solution rich in nutrients is used but that soon needs to be discarded. Thus, we envision that a low-cost alternative for the cultivation of Spirulina would be this waste coming from hydroponic cultivation. The aim of this work was to characterize the biomass of Arthospira sp grown in alternative culture media based on hydroponic effluent through a systematic review. The study concludes the need to supplement the residual medium with synthetic medium for its use.
\end{abstract}

Keywords: Arthrospira sp; Hydroponic waste; drainage medium; Biomass composition; microalgae.

\section{Caracterização da biomassa de Arthrospira sp (Spirulina) cultivada em solução de resíduo hidropônico: uma revisão}

\section{Resumo:}

A utilização da Spirulina (Arthospira sp) como fonte alimentar tem se destacado por ser uma fonte potencial de proteínas, ácidos graxos, vitaminas e outros. Porém, o meio de cultivo para sua produção ainda é caro. Observamos que em sistemas hidropônicos é utilizada uma solução rica em nutrientes, mas que logo precisa ser descartada. Dessa forma, vislumbramos que uma alternativa de baixo custo para o cultivo da espirulina seria esse resíduo oriundo do cultivo hidropônico. O objetivo deste trabalho foi caracterizar a biomassa de Arthospira $s p$ cultivada em meios de cultura alternativos a base de efluente hidropônico por meio de uma revisão sistemática. $O$ estudo conclui a necessidade de complementar o meio residual com meio sintético para seu uso.

Palavras-chave: Arthrospira sp; Resíduos hidropônicos; Meio de drenagem; Composição da biomassa; microalgas. 


\section{INTRODUCTION}

The use of microalgae and cyanobacteria as a food source, both for humans and animals, has stood out for having a potential source of proteins, unsaturated fatty acids, vitamins, minerals, pigments, enzymes, antibiotics and other biologically active metabolites. ${ }^{[1,2]}$ However, the potential associated with these microorganisms depends directly on variables associated with the growth of biomass, therefore, it is necessary to control $\mathrm{pH}$, light, temperature and nutrients.

Nutrients are supplied to the microorganism by a solution containing nitrogen, phosphorus, potassium, some salts and metals in lower concentrations which is designated as a culture medium and, in general, represents the most expensive cost for the production of biomass. ${ }^{[3]}$

The hydroponics technique uses a nutrient solution that feeds the plants replacing the soil. However, this solution needs to be discarded periodically, generating a drainage solution, rich in nutrients. [4]

Spirulina (Arthospira sp) is the cyanobacteria (blue-green alga) most used in animal and human food due to the high protein content in biomass (up to $60 \%$ of dry weight) and the high nutritional value associated with vitamins, minerals and acids fatty content, biological activity and easy digestibility. ${ }^{[5,6]}$ It is a species that has been approved by ANVISA (The brazilian Health surveillance agency) for human consumption. Due to the different strains of Spirulina, they can adapt to extreme environments (alkaline environments, saline environments, high temperatures and light, among others), their cultivation and consumption have been popularized in several parts of the world ".[5] Thus, composing an alternative medium based on hydroponic waste for the cultivation of cyanobacteria Arthospira sp becomes an interesting research possibility.

The objective of this work was to characterize the biomass of Arthospira $s p$ cultivated in alternative culture media based on hydroponic effluent through a systematic review in order to identify the effects of low-cost culture media on biomass compositions.

\section{METHODOLOGY}

The following keywords were used: "Microalgae", "hydroponics", "aquaponics", "tomatoes", "comparison", "Alternative media", "Cultive media", "NPK", "Spirulina", "Biomass composition", "Arthrospira", "aquaculture" in which 78 combinations were made. The base used was the "Sciencedirect" throughout the entire period available with filters for research articles and testing in title and throughout the document. A total of 49 articles were found on the search platforms, so the following exclusion criteria were applied:

- Withdrawal of publications that did not present the full article available;

- Adherence to the objectives of informational research;

- Duplicate publications on different platforms.

\section{RESULTS AND DISCUSSION}

After the composition of the systematic review, 19 articles were selected and part of these were used to characterize the biomass of Arthospira sp.

Evaluating the articles, it was noticed the absence of works that use Arthospira plantesis or Arthospira $s p$ in hydroponic solution. Thus, the only works found with an 
alternative solution close to those based on hydroponics for cultivation of the species Arthospira sp are based on aquaculture residues. ${ }^{[7,8]}$

The rest deal with the use of industrial and agro-industrial waste and synthetic alternative means as shown in Table 1.

Tabela 1 - Works that present Arthospira in alternative media.

\begin{tabular}{|c|c|c|}
\hline Ref. & Culture medium & Main Results \\
\hline$[7]$ & $\begin{array}{l}\text { Aquaculture } \\
\text { Wastewater }\end{array}$ & $\begin{array}{l}\text { The algae grow well in fish water with a specific growth rate of } \\
0.026 \mathrm{~h}-1(0.623 \text { day }-1) \text { and a doubling time of } 28 \mathrm{~h} \text {. These } \\
\text { growth parameters compare favorably with those reported in the } \\
\text { literature, indicating the adequacy of the cultivation of } \mathrm{S} \text {. platensis } \\
\text { in fish waters. }\end{array}$ \\
\hline$[8]$ & $\begin{array}{l}\text { Aquaculture } \\
\text { Wastewater }\end{array}$ & $\begin{array}{l}\text { The best results of growth parameters of Spirulina sp. LEB } 18 \\
\text { crops using wastewater aquaculture were obtained in experiments } \\
\text { with } 25 \text { and } 50 \% \text { Zarrouk supplementation. In these experiments, } \\
\text { the maximum biomass concentrations were equal }(p<0.05) \text { to the } \\
\text { control test without the addition of residual aquaculture water. In } \\
\text { addition, the maximum yield rates and the maximum growth } \\
\text { coefficients in these two experiments were about } 1.7 \text { and } 1.8 \\
\text { higher, respectively, than the results obtained in the control } \\
\text { cultivation. Although the experiment using } 75 \% \text { Zarrouk } \\
\text { supplementation showed a lower maximum biomass } \\
\text { concentration than the control. The fatty acid composition of the } \\
\text { biomass in the control and with } 25 \% \text { supplementation of Zarrouk } \\
\text { medium was observed in both experiments with the same profile. } \\
\text { The content of unsaturated fatty acids in the treatment with } 25 \% \\
\text { Zarrouk was higher. }\end{array}$ \\
\hline [9] & $\begin{array}{l}\text { Confectionary } \\
\text { wastes }\end{array}$ & $\begin{array}{l}\text { In this study, A. platensis grew very well in the residual } \\
\text { confectionery effluent during the different experimental runs of the } \\
22 \text { CCD (Central Composite Design). The seaweed can use sugar } \\
\text { present in the effluent. As expected, the results ensured the } \\
\text { adequacy of the use of A. platensis for growth in residual } \\
\text { confectionery effluent. In addition, the biochemical composition of } \\
\text { the biomass was } 20 \% \text { higher than the control after } 12 \text { days. O, b } \\
\text { carotenes (mg L1) was doubled. The levels of proteins, lipids and } \\
\text { carbohydrates increased by } 20 \%, 22.2 \% \text { and } 22.3 \% \text {, respectively. } \\
\text { However, chlorophyll decreased by } 12 \% \text { as the biomass became } \\
\text { pale and lost its typical blue-green color. }\end{array}$ \\
\hline [10] & $\begin{array}{l}\text { Zarrouk synthetic } \\
\text { medium with } \\
\text { added glycerol }\end{array}$ & $\begin{array}{l}\text { The addition of glycerol to Spirulina sp. (LEB 18) stimulated cell } \\
\text { growth ( } 3.00 \mathrm{~g} \text { L-1 of biomass, } 0.72 \mathrm{~g} \mathrm{~L}-1 \mathrm{~d}-1 \text { of maximum } \\
\text { productivity) and protein production }(69.78 \% \mathrm{w} \text { w-1), obtaining the } \\
\text { best results at } 0.05 \mathrm{~mol} \mathrm{~L}-1 \text {. The substrate application had a } \\
\text { significant effect on the composition of fatty acids. It was observed } \\
\text { that the increase in unsaturated fatty acids, mainly oleic acid, and } \\
\text { the reduction in saturated fatty acids, mainly palmitic, were } \\
\text { proportional to the increase in the concentration of glycerol in this } \\
\text { ambient. }\end{array}$ \\
\hline
\end{tabular}




\begin{tabular}{|c|c|l|} 
[11] & $\begin{array}{l}\text { Formulation of a } \\
\text { low-cost medium }\end{array}$ & $\begin{array}{l}\text { This investigation was carried out with the basic objective of } \\
\text { providing a simple and inexpensive ambient and our results clearly } \\
\text { indicate that the newly formulated solution RM6 is on the same } \\
\text { level as Zarrouk's solution with regard to the performance of } \\
\text { spirulina, when evaluated in terms of chlorophyll, protein or dry } \\
\text { biomass. }\end{array}$ \\
\hline [12] & $\begin{array}{l}\text { Wastewater can support the growth of Arthrospira platensis for the } \\
\text { production of biodiesel. A. platensis shows a wide range of } \\
\text { temperature tolerance; however, 30 }{ }^{\circ} \mathrm{C} \text { was considered more } \\
\text { suitable for the production of lipids. Change in light intensity from } \\
160 \text { to } 300 \mu \text { mol / m2 / s during the intermediate exponential phase } \\
\text { favors the production of saturated fatty acid in Arthrospira } \\
\text { platensis. }\end{array}$ \\
\hline
\end{tabular}

Thus, it became necessary to include other microalgae species, specifically Cholera sp, which stood out for having literature with the presence of hydroponicsbased residual solution, and in order to verify the effects that could occur with Spirulina were listed in Table 2.

Tabela 2 - Works that present alternative ways based on hydroponic, aquaponic or aquaculture cultivation residues.

\begin{tabular}{|c|c|c|c|}
\hline Ref. & Species & Culture medium & Results \\
\hline$[1]$ & $\begin{array}{c}\text { Chlorella } \\
\text { vulgari }\end{array}$ & $\begin{array}{l}\text { Residual } \\
\text { hydroponic } \\
\text { solution }\end{array}$ & $\begin{array}{l}\text { The cell density in the cultivation of the residual } \\
\text { hydroponic solution with } 25 \% \text { residue and } 75 \% \\
\text { deionized did not present any significant difference in } \\
\text { relation to the control (BBM). The other crops (SHR } \\
\text { and SHR50) were significantly lower than the control } \\
\text { crop, but did not show any statistical difference } \\
\text { between them. The cultivation of Chlorella vulgaris in } \\
\text { residual hydroponic solution represents an attractive } \\
\text { option for the development of nutritional supplements } \\
\text { due to the high protein content and biologically active } \\
\text { substances present in the cell biomass obtained in the } \\
\text { process. The residual hydroponic solution and its } \\
\text { respective dilutions (SHR50 and SHR25) proved to be } \\
\text { a good option as an alternative way of enviroment in } \\
\text { the cultivation of Chlorella vulgaris, enabling the } \\
\text { recycling of this residue in a sustainable way. }\end{array}$ \\
\hline$[4]$ & $\begin{array}{c}\text { Chlorella } \\
\text { vulgari }\end{array}$ & $\begin{array}{c}\text { Artificial } \\
\text { drainage } \\
\text { solution and a } \\
\text { spent drainage } \\
\text { solution that } \\
\text { had been used } \\
\text { in commercial } \\
\text { greenhouse } \\
\text { cultivation of } \\
\text { tomato } \\
\end{array}$ & $\begin{array}{l}\text { This study showed that microalgae have the } \\
\text { potential to reduce nutrient concentrations in the } \\
\text { production drainage solution in a hydroponic } \\
\text { greenhouse. Significant reductions in nitrogen and, in } \\
\text { particular, phosphorus concentration was observed. }\end{array}$ \\
\hline
\end{tabular}




\begin{tabular}{|c|c|c|c|} 
[13] & Chlorella spp & $\begin{array}{l}\text { Co-cultivation } \\
\text { with tomato in a } \\
\text { hydroponic } \\
\text { system }\end{array}$ & $\begin{array}{l}\text { Microalgae could be successfully co-cultivated with } \\
\text { entry to cultivation alone. In the EHS (eco-hydroponic } \\
\text { culture), the production of microalgal biomass and the } \\
\text { production of agricultural biomass were increased by } \\
\text { aerating the photosynthesis of the algae and by } \\
\text { fertilizing C of the crop root respiration and exudation, } \\
\text { respectively. In particular, the co-use of nutrients in the } \\
\text { nutrient solution by microalgae and culture can } \\
\text { increase the efficiency of nutrient use and minimize the } \\
\text { discharge of nutrients. }\end{array}$ \\
\hline [14] & $\begin{array}{c}\text { Platymonas } \\
\text { subcordiform } \\
\text { is }\end{array}$ & $\begin{array}{l}\text { Aquaculture } \\
\text { wastewater }\end{array}$ & $\begin{array}{l}\text { In conclusion, it was possible to couple the removal of } \\
\text { nitrogen and phosphorus from wastewater to algae } \\
\text { biomass and the production of biofuels. Platymonas } \\
\text { subcordiformis kelp can remove 87\% -95\% nitrogen } \\
\text { and 98\% -99\% phosphorus in sole aquaculture } \\
\text { wastewater. The algae biomass was } 8.9 \text { times greater } \\
\text { than the initial level. }\end{array}$ \\
\hline
\end{tabular}

Then, the effects of these alternative environments on microalgae were discussed and compared with those based on Arthospira aquaculture, and the similarities and effects on the biomass composition were identified to serve as an argument in the characterization of the Spirulina sp. By the way, it was observed that all experiments involving the hydroponic environment and aquaculture found optimistic results for the use of residual effluents. However, there is a need to complement this solution with another artificial solution in order to obtain greater results in the production of biomass and also by-products of high added value.

In addition, analyzing the articles, the presence of pre-treatment processes for residual effluent was identified in order to eliminate the presence of microorganisms negative to the development of microalgae and also to reduce or increase micronutrient levels, which may have inhibitory or catalytic effects, thus, high presence of metals like $\mathrm{Fe}$ and $\mathrm{Cu}$, reduction or excess of main nutrients and other effects, can interfere in the growth of Arthospira through alterations in the metabolism or reducing its activity and the presence of certain micronutrients and balanced nutrient reserves can lead to better drastic effects on growth. ${ }^{[2,7,15]}$

After analyzing each article, it was possible to verify a biomass composition with the expectation of reduced productivity if pure residual effluent is used and as a consequence a possible reduction of compounds with high added value, but if supplemented or treated for a specific purpose, to obtain a better or equivalent yield to synthetic cultivation media such as Zarrouk solution. ${ }^{[16]}$

Thus analyzing the articles makes it possible to suggest that the biomass of Arthospira $s p$ that best scores a crop in hydroponic wastewater will be a characteristic biomass between that of article [1] which is classified as Chlorella sp and the article [8] found in aquaculture culture medium being thus composed of a biomass and protein yield similar to the standard or higher Zarrouk medium and normal or below normal amount of carotenoids depending on the stress conditions of the hydroponic residue with reduction reduction up to $50 \%{ }^{[4]}$ 
Considering the case of the waste having an excess of metallic compounds such as $\mathrm{Fe}, \mathrm{Cu}$ and $\mathrm{Mo}$, there may be a reduction in biomass reduction in biomass and proteins. ${ }^{[15,17]}$

\section{CONCLUSION}

At the end of the study, it was possible to analyze the characteristic biomass of Arthospira sp when grown in hydroponic waste through the contribution of the work of other authors in order to verify the effects in comparison with a synthetic culture solution.

It was possible to observe a tendency to reduce biomass and by-products mainly when the microalgae suffer the effects of the excess of some micronutrients such as iron and copper, which is associated with the use of pure waste and without treatment, however its use is possible when supplemented with a synthetic solution in adequate proportion and with treatment to balance nutrients. Thus analyzing the articles makes it possible to suggest that the biomass of Arthospira sp will be a characteristic biomass between that of article [1] which is classified as Chlorella sp and the article [8] found in aquaculture culture medium being thus composed of a biomass and protein yield similar to the standard or higher Zarrouk medium and normal or below normal amount of carotenoids.

It is hoped that this study in the published works will serve as an approximation of the answer to the objective of the research project, but experimental studies are still needed in order to obtain results that prove the feasibility of using hydroponic effluent as a substrate for cyanobacteria.

\section{Acknowledgments}

We are grateful FAPESB for the scholarship granted under the project "PRODUCTION OF MICRO-ALGAE FOR FOOD PURPOSES USING EFFLUENT FROM HYDROPONIC CULTIVATION OF TOMATO", which was approved in application No. 3497/2019.

\section{REFERENCES}

1. BERTOLDI, F. C.; SANT'ANNA, E.; OLIVEIRA, J. L. B. Teor de clorofila e perfil de sais minerais de Chlorella vulgaris cultivada em solução hidropônica residual. Ciência Rural, v. 38, n. 1, p. 54-58, fev. 2008.

2. SONI, R. A.; SUDHAKAR, K.; RANA, R. S. Spirulina - From growth to nutritional product: A review. Trends in Food Science \& Technology, v. 69, p. 157-171, nov. 2017.

3. MORAIS JUNIOR, W. G. et al. Microalgae for biotechnological applications: Cultivation, harvesting and biomass processing. Aquaculture, v. 528, p. 735562, nov. 2020.

4. HULTBERG, M.; CARLSSON, A. S.; GUSTAFSSON, S. Treatment of drainage solution from hydroponic greenhouse production with microalgae. Bioresource Technology, v. 136, p. 401-406, maio 2013.

5. COSTA, J. A. V. et al. Operational and economic aspects of Spirulina-based biorefinery. Bioresource Technology, v. 292, p. 121946, nov. 2019. 
6. CHAMORRO-CEVALLOS, G. ASPECTOS NUTRICIONALES $Y$ TOXICOLÓGICOS DE SPIRULINA (ARTHROSPIRA). NUTRICION HOSPITALARIA, n. 1, p. 34-40, 1 jul. 2015.

7. WUANG, S. C. et al. Use of Spirulina biomass produced from treatment of aquaculture wastewater as agricultural fertilizers. Algal Research, v. 15, p. 5964, abr. 2016.

8. CARDOSO, L. G. et al. Spirulina sp. LEB 18 cultivation in outdoor pilot scale using aquaculture wastewater: High biomass, carotenoid, lipid and carbohydrate production. Aquaculture, v. 525, p. 735272, ago. 2020.

9. EL-KASSAS, H. Y.; HENEASH, A. M. M.; HUSSEIN, N. R. Cultivation of Arthrospira (Spirulina) platensis using confectionary wastes for aquaculture feeding. Journal of Genetic Engineering and Biotechnology, v. 13, n. 2, p. 145155, dez. 2015.

10. MORAIS, E. G. DE et al. Glycerol increases growth, protein production and alters the fatty acids profile of Spirulina (Arthrospira) sp LEB 18. Process Biochemistry, v. 76, p. 40-45, jan. 2019.

11. RAOOF, B.; KAUSHIK, B. D.; PRASANNA, R. Formulation of a low-cost medium for mass production of Spirulina. Biomass and Bioenergy, v. 30, n. 6, p. 537-542, jun. 2006.

12. HENA, S. et al. Dairy farm wastewater treatment and lipid accumulation by Arthrospira platensis. Water Research, v. 128, p. 267-277, jan. 2018.

13. ZHANG, J.; WANG, X.; ZHOU, Q. Co-cultivation of Chlorella spp and tomato in a hydroponic system. Biomass and Bioenergy, v. 97, p. 132-138, fev. 2017.

14. GUO, Z. et al. Microalgae cultivation using an aquaculture wastewater as growth medium for biomass and biofuel production. Journal of Environmental Sciences, v. 25, p. S85-S88, dez. 2013.

15. ZINICOVSCAIA, I. et al. Metal ions removal from different type of industrial effluents using Spirulina platensis biomass. International Journal of Phytoremediation, v. 21, n. 14, p. 1442-1448, 6 dez. 2019.

16. ZARROUK, C. Contribution a l'etuded'unecyanophycee: influence de divers facteurs physiques etchimiquessur la croissance et la photosynthese de Spirulina maxima (Setch et Gardner) Geitler. Theises. Faculty of Science.Universite des Paris; 1966.

17. ISMAIEL, M. M. S.; PIERCEY-NORMORE, M. D.; RAMPITSCH, C. Proteomic analyses of the cyanobacterium Arthrospira (Spirulina) platensis under iron and salinity stress. Environmental and Experimental Botany, v. 147, p. 63-74, mar. 2018. 